Original Research Paper

\title{
Sosialisasi Desa Tanggap Bencana Masyarakat Desa Sedau Kecamatan Narmada Kabupaten Lombok Barat
}

\author{
Kusmiyati $^{1^{*}}$, Ni Luh Eka Widya Santi ${ }^{2}$, Ni Putu Melania Putri ${ }^{3}$, Ni Putu Virgi Eka Ayu Rasta ${ }^{2}$, \\ Sarah Kurnia ${ }^{2}$ \\ ${ }^{1}$ Program Studi Pendidikan Biologi, FKIP, Universitas Mataram \\ ${ }^{2}$ Program Studi Pendidikan Matematika, FKIP, Universitas Mataram \\ ${ }^{3}$ Program Studi Pendidikan Bahasa Indonesia dan Sastra, FKIP Universitas Mataram
}

https://doi.org/10.29303/jpmpi.v3i2.1419

Sitasi: Kusmiyati., Santi, N. L. E., Putri, N. P. M., Rasta, N. P. V. E. A \& Kurnia, S. (2022). Sosialisasi Desa Tanggap Bencana Masyarakat Desa Sedau Kecamatan Narmada Kabupaten Lombok Barat. Jurnal Pengabdian Magister Pendidikan IPA, 5(1)

\section{Article history}

Received: 11 Januari 2022

Revised: 01 Februari 2022

Accepted: 07 Februari 2022

*Corresponding Author:

Kusmiyati, Program Studi Pendidikan Biologi, FKIP, Universitas Mataram, Indonesia;

Email :

kusmiyati.fkip@unram.ac.id

\begin{abstract}
Bencana merupakan peristiwa tak terduga yang menyebabkan korban jiwa, kerugian harta benda, dan kerusakan lingkungan. Desa Sedau, Kecamatan Narmada, Kabupaten Lombok Barat berlokasi di daerah perbukitan, sehingga daerah tersebut berpotensi mengalami bencana salah satunya yaitu tanah longsor. Tujuan kegiatan sosialisasi ini untuk untuk meningkatkan kesadaran masyarakat desa mengenai Desa Tanggap Bencana dan mempersiapkan pencegahan terhadap bencana alam yang mungkin akan terjadi, namun bisa dicegah sejak dini. Kegiatan ini dilakukan dengan cara memberikan edukasi kepada masyarakat setempat terkait kebencanaan. Metode yang digunakan saat penyampaian materi adalah metode ceramah yang diakhiri dengan sesi diskusi/tanya jawab. Kegiatan sosialisasi ini dilaksananakan pada hari Sabtu tanggal 18 Desember 2021. Pelaksanaan sosialisasi berjalan lancar, sebagian besar masyarakat desa Sedau hadir dan,masyarakat yang hadir mengikuti dari awal hingga akhir. Selama kegiatan, masyarakat sangat antusias terhadap materi yang disampaikan, terlihat dari banyaknya pertanyaan yang diajukan. Kesimpulan dari kegiatan ini adalah terjadi peningkatan kewaspadaan dan kesadaran masyarakat terlihat dari setelah selesai sosialisasi beberapa masyarakat bertanya terkait bagaimana cara untuk membuat laporan jika terjadi bencana. Saran: Kegiatan serupa dapat dilakukan secara berkala, baik di tempat yang sama atau di tempat yang berbeda, dengan sasaran orang tua dan anak-anak, untuk meningkatkan pengetahuan, kesadaran, dan kewaspadaan dalam penanganan bencana.
\end{abstract}

Keywords: Sosialisasi, tanggap bencana, Desa Sedau

\section{Pendahuluan}

Indonesia merupakan negara yang memiliki iklim tropis dan subtropic sehingga menyebabkan Indonesia hanya memiliki dua musim yakni musim hujan dan musim kemarau. Hal ini menyebabkan tanah yang ada di Indonesia menjadi tanah yang sangat subur. Selain itu, Indonesia terletak pada pertemuan tiga lempeng dunia yaitu lempeng Eurasia, lempeng Pasifik dan lempeng Australia yang selalu bergerak dan saling menumbuk (Arifianti, 2011). Tumbukan tersebut menyebabkan Indonesia menjadi negara yang rawan bencana alam, seperti gempa, tsunami, gunung meletus, banjir hingga tanah longsor. 
Bencana merupakan peristiwa tak terduga yang menyebabkan korban jiwa, kerugian harta benda, dan kerusakan lingkungan. Bencana tanah longsor bersifat lokal dan jika dibiarkan dalam jangka waktu yang lama, maka akan menyebabkan lebih banyak kerugian dibandingkan bencana lain. Berdasarkan data statistik, dalam kurun waktu 2005 - 2011 tercatat 809 lokasi kejadian tanah longsor yang tersebar di seluruh Indonesia dengan 2.484 orang tewas (PVMBG, 2012). Menurut llahi (2021), data Badan Nasional Penanggulangan Bencana (BNPB) periode Januari-Oktober 2021, sebanyak 2.208 kejadian bencana alam terjadi di Indonesia dengan 406 kejadian merupakan tanah longsor.

Terkait hal tersebut pemerintah melaksanakan Pengurangan Risiko Bencana (PRB) dengan landasan hukum UU RI no. 24 tahun 2007 tentang "Penanggulangan Bencana" sehingga dapat mengubah pola pikir masyarakat untuk dapat melakukan berbagai upaya sebelum terjadinya bencana, seperti tanah longsor salah satunya.

Sedau merupakan salah satu desa yang berada di kecamatan Narmada, Kabupaten Lombok Barat, Provinsi Nusa Tenggara Barat, terletak kurang lebih $11 \mathrm{~km}$ di sebelah timur kota Mataram. Menurut data di web desa Sedau (2021), jumlah KK di desa sedau adalah 1.753, dimana penduduk laki-laki berjumlah 2.526 jiwa, sedangkan penduduk perempuan berjumlah 2.407 jiwa. Masyarakat desa Sedau sebagian besar penghasilannya berasal dari sektor pertanian, disamping itu wilayahnya merupakan kawasan yang sangat potensial di bidang agrowisata, karena kawasan ini menjadi pusat pertanian dan perkebunan yang cukup luas terutama buah-buahan.

Lebih lanjut dijelaskan, luas wilayah desa Sedau, Kecamatan Narmada, Kabupaten Lombok Barat adalah $560.000 \mathrm{Ha}$ yang terbagi menjadi enam dusun, yaitu dusun Eyat Bintang, Sedau Gondang, Sedau Dese, Paok Gading, Lebah Suren dan Selen Aik. Adapun kondisi tanah di desa Sedau sangat subur, dibuktikan dengan sebagian besar lahan di desa tersebut menjadi lahan pertanian dan perkebunan walaupun di beberapa wilayah agak sulit ditumbuhi beberapa tanaman karena terlalu lembab.
Kelembaban tanah pada Desa Sedau menyebabkan dusun di beberapa desa ini menjadi rawan bencana longsor, dua di antaranya desa yang telah terjadi bencana longsor dan memiliki potensi pengikisan daerah pemukiman yaitu dusun Lebah Suren dan dusun Selen Aik. Dusun Lebah Suren merupakan dusun yang terletak di dataran tinggi, berdampingan dengan jurang dan sungai yang sangat tinggi. Kondisi ini, ketika terjadi hujan deras maka air dari bukit akan turun, jatuh ke sungai tersebut dan menyebabkan pengikisan tanah, sehingga akan rentan terjadinya tanah longsor.

Sebagai mahasiswa, pengabdian kepada masyarakat merupakan salah satu hal yang harus dilakukan sesuai dengan Tri Dharma Perguruan Tinggi salah satunya adalah KKN (Kuliah Kerja Nyata). Dengan adanya permasalahan tersebut, maka mahasiswa KKN PLP Universitas Mataram periode 2021-2022 mengadakan sosialisasi untuk masyarakat Desa Sedau yang bertujuan untuk meningkatkan kesadaran masyarakat desa mengenai Desa Tanggap Bencana dan mempersiapkan pencegahan terhadap bencana alam yang mungkin akan terjadi namun bisa dicegah sejak dini. Rangkaian kegiatan yang dilakukan dalam sosialisasi tersebut adalah pemaparan materi dan sesi tanya jawab antara masyarakat dan narasumber yang dipandu oleh moderator sosialisasi.

\section{Metode}

Kegiatan sosialisasi ini dilaksanakan pada hari Sabtu tanggal 18 Desember 2021. Metode pelaksanaan yang dilakukan oleh mahasiswa Kuliah Kerja Nyata PLP Universitas Mataram periode November 2021 - Januari 2022 adalah metode ceramah dan tanya jawab. Metode ceramah digunakan untuk memberikan sosialisasi mengenai Desa Tanggap Bencana yang disampaikan oleh Bidang Analisis Kebencanaan BPBD Provinsi Nusa Tenggara Barat. Metode tanya jawab/ diskusi digunakan untuk melihat pemahaman masyarakat terhadap materi yang telah di sampaikan

Selain mengenai tanggap bencana, materi yang diberikan juga mengenai Desa Tangguh Bencana, yang merupakan program BPBD dalam memberikan penyuluhan kepada masyarakat. 
Karena jika hanya mengandalkan pemerintah dalam mencegah bencana akan sangat sulit, sehingga perlu gerakan dari masyarakat lansung yang secara mandiri waspada terhadap kondisi lingkungannya sendiri.

Menumbuhkan kesadaran masyarakat tentu tidak mudah, namun cara ini dilakukan agar masyarakat dapat membuka wawasan lebih luas mengenai banyak kewaspadaan yang harus ditanggapi agar bencana yang akan terjadi dapat diminimalisir kerugian baik materiil maupun fisik.

\section{Hasil dan Pembahasan}

Nusa Tenggara Barat merupakan daerah rawan bencana, dari 14 bencana yang ada di Indonesia 13 di antaranya terjadi di Provinsi NTB. Begitu pula dengan Desa Sedau, desa ini berada di dataran tinggi sehingga bencana yang paling sering terjadi adalah tanah longsor.

Proses terjadinya tanah longsor yaitu dimulai dengan peresapan air ke dalam tanah yang mengakibatkan penambahan bobot tanah. Jika air yang meresap ke dalam tanah tersebut sampai ke tanah yang kedap air (bidang gelincir), maka akan menjadikan kondisi tanah menjadi licin. Oleh karena itu, tanah pelapukan yang ada di atasnya akan menjadi rentan terjadi longsor (Sutarno, 2012). Pada umumnya, tanah longsor disebabkan oleh tiga hal. Diantaranya yaitu faktor dakhil, kondisi luar dari suatu medan dan faktor pemicu lainnya (Arsyad, dkk, 2018).

Adapun struktur geologi, permeabilitas tanah dan kedalaman pelapukan batuan termasuk dalam faktor dakhil. Sementara itu, kemiringan, penggunaan lahan dan banyaknya dinding terjal ini masuk dalam kategori penyebab tanah longsor yang dari kondisi luar suatu medan (Susanti, dkk, 2017). Faktor pemicu lainnya yaitu adanya curah hujan tinggi dan terjadinya gempa bumi. Berdasarkan halhal tersebut, pada dasarnya tanah longsor itu disebabkan oleh dua faktor utama yaitu faktor alam dan manusia (Juhadi, dkk, 2016).

Ada 6 dusun di desa Sedau dan 2 dusun diantaranya termasuk daerah rawan bencana longsor. Dusun tersebut adalah dusun Selen Aik dan Dusun Lebah Suren. Berdasarkan bencana tanah longsor yang terjadi tersebut, perlu adanya mitigasi yang harus dilakukan oleh pemerintah dan masyarakat sekitar. Mitigasi bencana tersebut perlu dilakukan saat terjadinya bencana, dan setelah bencana tanah longsor tersebut terjadi. Hal ini dilakukan untuk mengantisipasi bencana tanah longsor susulan dan akibat yang ditimbulkan dari bencana tersebut. Mitigasi bencana itu dapat dibagi menjadi dua jenis, yaitu mitigasi struktural dan nonstruktural. Mitigasi struktural meliputi pembuatan infrastruktur yang kuat yang dapat meminimalisasi dampak dari tanah longsor. Pengelolan tanah longsor dan pelatihan kepada masyarakat pada daerah rawan tanah longsor mengenai mitigasi-mitigasi yang harus diakukan saat terjadi dan setelah terjadinya bencana tanah longsor ini termasuk dalam kategori mitigasi nonstruktural (Rahman, 2015).

Strategi mitigasi tanah longsor antara lain:

1. Pemetaan, menyajikan informasi visual tentang tingkat kerawanan bencana alam di suatu wilayah, sebagai masukan kepada masyarakat dan atau pemerintah kabupaten/kota dan provinsi sebagai data dasar untuk melakukan pembangunan wilayah agar terhindar dari bencana.

2. Penyelidikan, mempelajari penyebab dan dampak dari suatu bencana sehingga dapat digunakan dalam perencanaan penanggulangan bencana dan rencana pengembangan wilayah.

3. Pemeriksaan, melakukan penyelidikan pada saat dan setelah terjadi bencana, sehingga dapat diketahui penyebab dan cara penanggulangannya.

4. Pemantauan, dilakukan di daerah rawan bencana, pada daerah strategis secara ekonomi dan jasa, agar diketahui secara dini tingkat bahaya, oleh pengguna dan masyarakat yang bertempat tinggal di daerah tersebut.

5. Sosialisasi, memberikan pemahaman kepada Pemerintah Provinsi/ Kabupaten/ Kota atau masyarakat umum, tentang bencana tanah longsor dan akibat yang ditimbulkannya. Sosialisasi dilakukan dengan berbagai cara seperti menerbitkan buku tentang bencana, mengirimkan poster, booklet, dan leaflet atau dapat juga secara langsung kepada masyarakat dan aparat pemerintah (Yukni, 2015). 


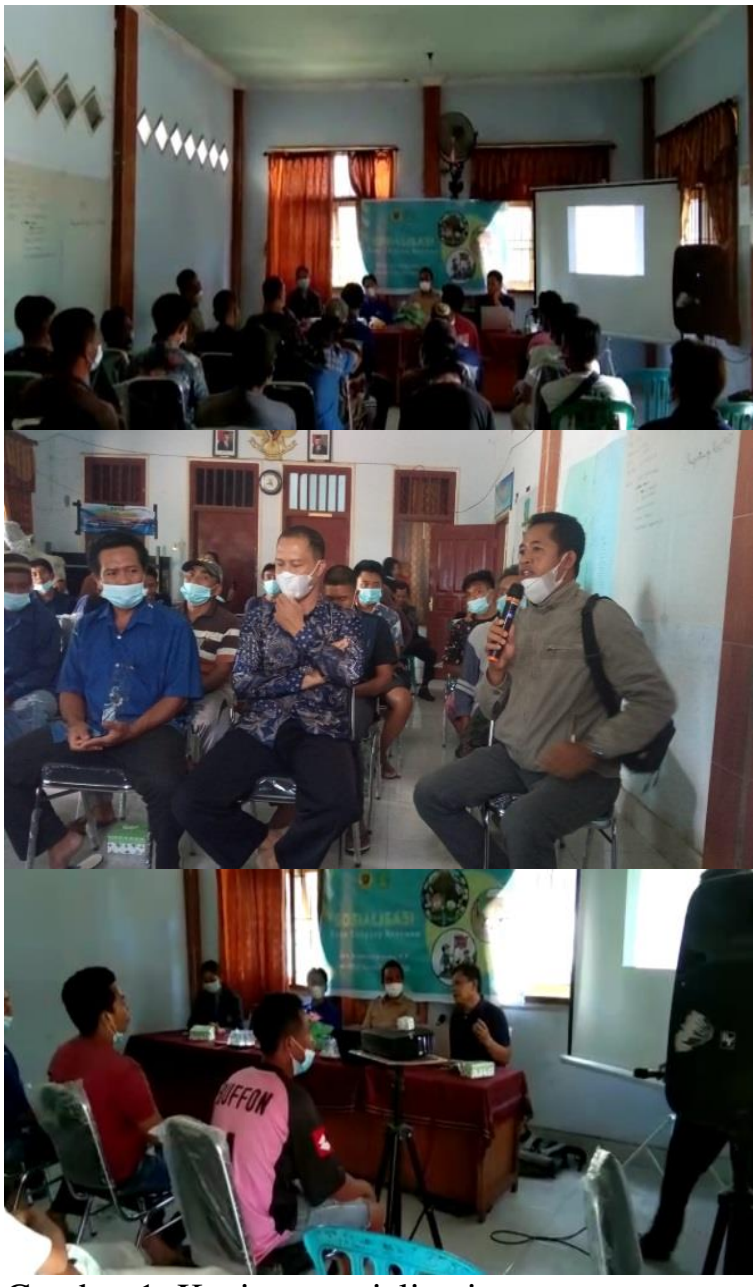

Gambar 1. Kegiatan sosialisasi

\section{Kesimpulan}

Berdasarkan hasil uraian di atas dapat disimpulkan sebagai berikut: Terjadi peningkatan kewaspadaan dan kesadaran masyarakat, terlihat dari setelah selesai sosialisasi beberapa masyarakat bertanya terkait bagaimana cara untuk membuat laporan jika terjadi bencana

\section{Ucapan Terimakasih}

Terimakasih kepada Universitas Mataram dan LPPM Universitas Mataram, yang telah memfasilitasi kegiatan ini dan juga kepada semua pihak yang telah mendukung pelaksanaan kegiatan ini.

\section{Daftar Pustaka}

\section{Arifianti Y. 2015. Buku Mengenal}

Tanah Longsor Sebagai Media Pembelajaran Sejak Dini. Bandung: Pusat Vulkanologi dan Mitigasi Bencana Geologi.

Arsyad, U., Barkey, R., Wahyuni. Dan Matandung, K. K. (2018). Karakteristik Tanah Longsor di Daerah Aliran Sungai Tangka. Jurnal Hutan dan Masyarakat, 10(1), 203-214.

Juhadi, Setyaningsih, W. dan Kurniasari, N. (2016). Pola Perilaku Masyarakat dalam Pengurangan Resiko Bencana Tanah Longsor di Kecamatan Banjarwangu Kabupaten Banjarnegara Jawa Tengah. Jurnal Geografi, 13(2), 217-224.

Rahman, A. Z. (2015). Kajian Mitigasi Bancana Tanah Longsor di Kabupaten Banjarnegara. Jurnal Manajemen dan Kebijakan Publik, 1(1).

Susanti, P. D., Miardini, A. dan Harjadi, B. (2017). Analisis Kerentanan Tanah Longsor Sebagai Dasar Mitigasi di Kabupaten Banjarnegara. Jurnal Penelitian Pengelolaan Daerah Aliran Sungai, 1(1), 49-59.

Sutarno. (2012). Studi Kerentanan Gerakan Massa Batuan dan Daerah Rawan Longsor Lahan di Kabupaten Purworejo. Jurnal Ilmu Tanah dan Agroklimatologi, 9(2), 131-137.

Winda Sari, dkk. 2020. Optimalisasi Perilaku Hidup Bersih dan Sehat (PHBS) Guna Meningkatkan Kesejahteraan Masyarakat Desa Bawu Kecamatan Batealit Kabupaten Jepara jawa Tengah. Semarang: Pusat Pengembangan KKN.

llahi, Kunia. 2021. BNPB : 2.203 Bencana Periode Januari hingga Oktober 2021, Terbanyak di Jawa. Diakses pada 5 Januari 2022, dari https://www.google.com/amp/s/www.inews.i d/amp/news/nasional/bnpb-2203-bencanaperiode-januari-hingga-oktober-2021terbanyak-di-jawa

Desa Sedau. 2021. Sedau desa buah. Diakses pada 5 Januari 2022, dari http://sedau.desa.id/potensi/read/sedau-desabuah-5201032007/0 